\title{
USAHA PENGEMBANGBIAKAN SAPI BALI KELOMPOK TANI (KT) MARIN TASI DAN BERO SEMBADA DI DESA KAPITAN MEO, KABUPATEN MALAKA
}

Maria Krova, G.A.Yudi Lestari, Y. Umbu Laiya Sobang

Fakultas Peternakan Undana, J1. Adisucipto Penfui Kupang. Email: mariakrova@ yahoo.com

\begin{abstract}
ABSTRAK
Upaya untuk menunjang klaster penggemukan sapi Bali yang dilakukan oleh KT Bero Sembada adalah memproduksi sendiri sapi Bali bakalan dan memasok sapi Bali bakalan dari luar, antara lain dari KT Marin Tasi. Solusi yang diperoleh dari pelaksanaan IbM ini, antara lain: 1) meningkatkan pemahaman peternak mengenai pentingnya perencanaan usaha ternak, pembukuan usaha ternak, manajemen pengembangbiakan, kebutuhan pakan dan nutrisi untuk setiap tahapan reproduksi sapi Bali, peranan koperasi untuk pengembangan usaha ternak sapi; 2) merancang metode perencanaan usaha ternak sederhana, pembukuan usaha sederhana, dan sistem akuntansi koperasi yang sederhana; 3) Meningkatkan keterampilan peternak dan pengurus UBSP dalam melakukan perencanaan usaha ternak sapi, pembukuan usaha ternak sapi, dan pembukuan UBSP, yang terdiri dari: kas UBSP, Rekapitulasi kas UBSP, Kertas Kerja, Neraca keuangan UBSP, dan laporan perhitungan rugi laba UBSP. Metode pendekatan yang digunakan dalam kegiatan ini adalah penyuluhan, pelatihan, dan ujicoba.
\end{abstract}

Kata Kunci: Kelompok Tani, Bero Sembada dan Marin Tasi, Pengembangbiakan, Sapi Bali 


\section{PENDAHULUAN}

Klaster adalah "konsentrasi geografis yang menghubungkan berbagai pelaku usaha, pemasok, jasa pelayanan, industri pendukung dan kelembagaan terkait (Perguruan Tinggi, pemerintah, dan asosiasi perdagangan) dalam suatu bidang tertentu yang saling bersaing dan juga bekerjasama" (Porter, 2000). Berdasarkan konsepnya, salah satu kunci keberhasilan klaster adalah interaksinya dengan stakeholder untuk mendapatkan berbagai kebutuhannya, antara lain: sumber pemasok input, mengakses modal, pemasaran output, serta pembelajaran teknologi dan inovasi.

Saat ini telah terbentuk beberapa klaster penggemukan sapi Bali berbasis organik di NTT, namun yang berkembang paling pesat adalah Kelompok Tani (KT) Bero Sembada yang diketuai oleh Antonius Tuna. Dalam menunjang klaster penggemukan tersebut strategi yang dikembangkan KT Bero Sembada adalah memproduksi sendiri sapi Bali bakalan dan memasok sapi Bali bakalan dari luar, antara lain KT Marin Tasi. KT Marin Tasi merupakan salah satu kelompok yang dibentuk oleh Pemda untuk usaha pengembangbiakan (Cow Calf Operation) sapi Bali yang diketuai oleh Nikodemus Neno. Jumlah peternak anggota setiap KT sebanyak 25 orang sehingga keseluruhannya sebesar 50 peternak. Kedua KT tersebut terdapat di Desa Kapitan Meo yang masuk dalam wilayah Kecamatan Laen Manen Kabupaten Malaka. Kabupaten Malaka merupakan salah satu kabupaten yang berbatasan langsung dengan Negara Timor Leste dan merupakan daerah yang sangat strategis untuk kepentingan bisnis maupun tujuan wisata. Perekonomian di wilayah ini berkembang cukup pesat karena merupakan salah satu daerah penopang perekonomian bagi negara tetangga Timor Leste.

Berdasarkan hasil survei, dari 50 peternak pada kedua KT tersebut sebanyak 65,38 persennya tidak pernah mengenyam pendidikan, 21,15 persen berpendidikan Sekolah Dasar, 9,62 persen berpendidikan Sekolah Lanjutan Tingkat Pertama, dan hanya 3,85 persen berpendidikan Sekolah lanjutan Tingkat Atas. Terlihat bahwa peternak anggota KT pada umumnya memiliki tingkat pendidikan formal yang relatif rendah. Apabila dilihat dari usia, maka ratarata usia dari peternak anggota KT adalah 55 tahun, dimana usia termuda adalah 26 tahun dan tertua 70 tahun. Sebagian besar peternak anggota KT yaitu sebesar 75 persen terkonsentrasi pada usia produktif 15-55 tahun. Sedangkan sisanya sudah masuk dalam 
kategori usia tidak produktif atau di atas 55 tahun. Gambaran tingkat pendidikan dan usia yang dimiliki peternak anggota KT di atas, mengindikasikan perlu diupayakan berbagai pendekatan agar dapat memperbaiki presepsi dan sikap yang belum mendukung pengembangan sapi Bali.

Sebagai salah satu model pengembangan agribisnis, klaster usaha penggemukan harus menjadi penarik yang efektif untuk memproduksi bakalan. Namun dalam pelaksanaannya terdapat banyak faktor yang menyebabkan usaha pengembangbiakan sulit berkembang seirama dengan usaha penggemukan. Usaha pengembangbiakan yang hanya dilakukan oleh peternakan rakyat memiliki masalah urgen karena adanya indikasi kelangkaan. Hasil kajian Krova (2015) menunjukkan bahwa saat ini ketersediaan sapi Bali bakalan di Kabupaten Belu dan Malaka semakin langka sehingga walaupun pedet sapi baru berumur 1 tahun sudah dibeli untuk bakalan penggemukan.

Fenomena tersebut terjadi karena berbagai permasalahan dalam usaha pengembangbiakan belum mendapatkan solusi.

\section{MASALAH}

Permasalahan yang dialami mitra saat ini adalah sebagai berikut:

1. Sistem pengembangbiakan sapi Bali belum direncanakan sesuai dengan potensi pakan yang dimiliki atau sebaliknya budidaya pakan belum disesuaikan dengan kemampuan pengembangbiakan sapi Bali.

2. Pemenuhan kebutuhan pakan untuk pengembangbiakan sapi Bali baik dari hijauan, legum, maupun suplemen masih sangat rendah dan belum disesuaikan dengan standar kebutuhan setiap tahapan reproduksi.

3. Manajemen pengembangbiakan (kawin, bunting, partus, dan penyapihan) belum dikelola dengan baik sehingga menyebabkan kegagalan dalam tahapan-tahapan reproduksi tersebut.

4. Manajemen keuangan peternak belum memberikan prioritas pada kegiatan produktif seperti halnya pengembangan usaha ternak sapi Bali tetapi lebih pada kegiatan-kegiatan konsumtif.

5. Pembukuan UBSP yang lengkap dan benar masih sulit dilakukan oleh pengurus sebagai salah satu persyaratan untuk menjadi koperasi. 


\section{METODE PELAKSANAAN}

Metode pendekatan yang digunakan dalam kegiatan ini adalah penyuluhan, pelatihan, dan ujicoba. Penyuluhan dilakukan untuk membekali pengetahuan dan pemahaman akan berbagai permasalahan pengembangbiakan sapi Bali baik dalam bidang perencanaan maupun teknis pembibitan yang dihadapi dan solusi yang harus dilakukan agar permasalahan tidak berkelanjutan. Pendekatan pelatihan ditujukan untuk meningkatkan keterampilan peternak dalam menjalankan manajemen produksi bakalan dan keuangan UBSPnya. Metode uji coba dilakukan agar peternak anggota kelompok dapat mempraktekan apa yang diperoleh dari penyuluhan dan pelatihan.

\section{HASIL YANG DICAPAI}

\section{Kegiatan Penyuluhan dan Diskusi}

Kegiatan penyuluhan dilaksanakan pada hari minggu tanggal 1 Juli 2017 yang dihadiri oleh 47 peserta dari kedua kelompok mitra, ketua kelompoknya masing-masing, dan aparat Desa Kapitan Meo. Kehadiran aparat desa merupakan bentuk dukungan pemerintah desa terhadap usahaternak sapi Bali yang banyak dilakukan oleh masyarakatnya. Kegiatan penyuluhan ini berlangsung dengan baik dilihat dari antusiasnya peternak peserta dalam menyampaikan permasalahan yang dihadapi dan diskusi baik tentang aspek perkandangan, pembibitan dan reproduksi, pakan, serta motivasi untuk keberlanjutan UBSP. Selain itu dosen yang bertindak sebagai penyuluh pun berdiskusi dengan peternak menyangkut pengalaman mereka dalam mengatasi persoalan-persoalan berusaha ternak sapi. Kondisi ini tercipta karena iklim yang kondusif baik antar tim, tim dengan peternak peserta, serta dukungan dari pemerintah desa. Berikut dijelaskan beberapa kegiatan penyuluhan yang diberikan.
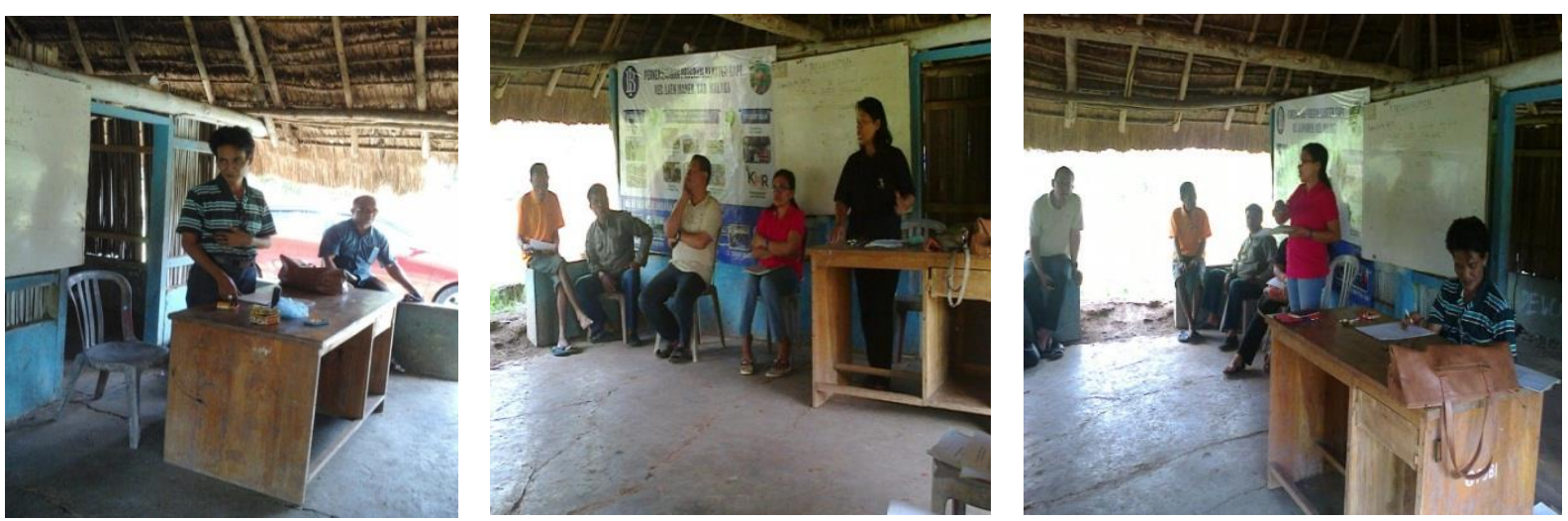

Gambar 1. Kegiatan Penyuluhan yang dilakukan oleh Tim Pelaksana PKM 
Penyuluhan tentang manajemen perkandangan memberikan pengetahuan dan pemahaman kepada peternak tentang fungsi kandang, konstruksi, dan macam-macam kandang dalam usaha pengembangbiakan. Informasi tentang manajemen perkandangan ini penting karena selama ini ternak sapi bibit tidak dikandangkan. Meningkatnya pengetahuan dan pemahaman peternak tentang pentingnya manajemen perkandangan dalam usaha pengembangbiakan diharapkan dapat meningkatkan produktivitas ternak

Fungsi kandang bagi ternak pada umumnya, adalah:

1. Melindungi ternak dari perubahan cuaca atau iklim yan ekstrem (panas, hujan dan angin).

2. Mencegah dan melindungi ternak dari penyakit.

3. Menjaga keamanan ternak dari pencurian.

4. Memudahkan pengelolaan ternak dalam proses produksi seperti pemberian pakan, minum, pengelolaaan kompos dan perkawinan.

5. Meningkatkan efisiensi penggunaan tenaga kerja.

Konstruksi, model, dan bahan kandang sangat tergantung pada sistim dan tipe usaha yang dilakukan. Pada sistem semi intensif dan ekstensif seperti yang dilakukan peternak anggota kedua KT ini, bangunan kandang biasanya lebih sederhana meliputi bahan, model, dan konstruksinya. Beberapa hal lainnya yang perlu diketahui adalah persyaratan kandang, tipe kandang, dan tata laksana perkandangan.

Macam kandang berdasarkan kegunaannya:

1. Kandang pembibitan, untuk pemeliharaan induk/calon induk

2. Kandang beranak atau kandan menyusui, untuk ternak sapi yang bunting tua (7-8 bulan) sampai menyapih pedetnya.

3. Kandang pembesaran, untuk memelihara pedet lepas sapi (4-7 bulan) sampai dewasa (1824 bulan)

4. Kandang penggemukan, untuk memelihara ternak sapi jantan dewasa selama digemukan.

5. Kandang paksa/kandang jepit, untuk perkawinan sisiten IB, perawatan kesehatan (potong kuku), pengambilan semen, dan penimbangan.

6. Kandang pejantan, untuk memelihara ternak sapi jantan dewasa yang digunakan sebagai pemacek.

7. Kandang karantina, untuk mengisolasi ternak sapi yang sakit dari ternak lainnya. 
Manajemen Pembibitan perlu diketahui oleh peternak, terutama menyangkut bagaimana menseleksi bibit yang baik, pengadaan ternak pengganti, pengeluaran (afkir) dan pencatatan. Seleksi bibit sapi potong dilakukan berdasarkan performan anak dan individu calon bibit sapi potong tersebut, dengan mempergunakan kriteria seleksi sebagai berikut:

1. Sapi Induk

a. sapi induk harus dapat menghasilkan anak secara teratur;

b. anak jantan maupun betina tidak cacat dan mempunyai rasio bobot sapih umur 205 hari di atas rata-rata.

2. Calon Pejantan

a. bobot sapih terkoreksi terhadap umur 205 hari umur induk dan musim kelahiran, di atas rata-rata

b. bobot badan umur 365 hari di atas rata-rata

c. pertambahan bobot badan antara umur 1-1,5 tahun di atas rata-rata

d. bobot badan umur 2 tahun di atas rata-rata

e. libido dan kualitas spermanya baik

f. penampilan fenotipe sesuai dengan rumpunnya.

3. Calon induk

a. bobot sapih terkoreksi terhadap umur 205 hari umur induk dan musim kelahiran, di atas rata-rata.

b. bobot badan umur 365 hari di atas rata-rata .

c. penampilan fenotipe sesuai dengan rumpunnya

Pengadaan ternak pengganti (replacement stock), dilakukan sebagai berikut:

1. Calon bibit betina dipilih $25 \%$ terbaik untuk replacement, $10 \%$ untuk pengembangan populasi kawasan, 60\% dijual ke luar kawasan sebagai bibit dan 5\% dijual sebagai ternak afkir (culling).

2. Calon bibit jantan dipilih $10 \%$ terbaik pada umur sapih dan bersama calon bibit betina $25 \%$ terbaik untuk dimasukkan pada uji performan.

Pengeluaran ternak yang sudah dinyatakan tidak memenuhi persyaratan bibit (afkir/culling), dilakukan dengan ketentuan sebagai berikut: 
1. Untuk bibit rumpun murni, 50\% sapi bibit jantan peringkat terendah saat seleksi pertama (umur sapih terkoreksi) dikeluarkan dengan di kastrasi dan $40 \%$ nya dijual ke luar kawasan.

2. Sapi betina yang tidak memenuhi persyaratan sebagai bibit (10\%) dikeluarkan sebagai ternak afkir (culling).

3. Sapi induk yang tidak produktip segera dikeluarkan.

Setiap usaha pembibitan sapi potong hendaknya melakukan pencatatan (recording). pencatatan (recording) tersebut meliputi: rumpun; silsilah; perkawinan (tanggal, pejantan, IB/kawin alam); kelahiran (tanggal, bobot lahir); penyapihan (tanggal, bobot badan); beranak kembali (tanggal, paritas); pakan (jenis, konsumsi); vaksinasi, pengobatan (tanggal, perlakuan/ treatment); mutasi (pemasukan dan pengeluaran ternak). Manfaat pencatatan ini, antara lain: mencegah terjadinya inbreeding, memudahkan seleksi ternak, dan membantu pengambilan keputusan penanganan, perawatan dan pengoabatan ternak.

Penyuluhan Insemnasi Buatan (IB) kepada peternak memberikan pemahaman tentang beberapa cara untuk dapat memperoleh ternak-ternak yang bertumbuh secara cepat dan dalam waktu yang singkat. Teknologi IB hanyalah alat untuk dapat memasukan atau menyampaikan sperma (bibit jantan) ke dalam saluran kelamin betina untuk membuahi telur betina yang berahi. Oleh karena IB hanya alat maka dalam pelaksanaannya membutuhkan banyak pihak atau komponen untuk dapat menyukseskan program IB ini. Dengan demikian cakupan atau ruang lingkup IB bukan hanya terbatas pada bagamana teknik memasukan bibit jantan kedalam saluran kelamin betina saja. Akan tetapi teknologi IB meliputi seleksi dan pemeliharaan jantan unggul, latihan penampungan bibit, latihan inseminator, seleksi betina akseptor, pemeliharaan dan pengamatan berahi, pelayanan IB dan pengamatan berahi sapi betina setelah beranak, pemeliharaan anak sapi sejak lahir sampai disapih (sole anak) dan menggemuk an atau menjualnya. Untuk itu berarti teknologi IB terkait atau berhubungan dengan banyak pihak seperti pihak yang mempunyai sapi jantan bibit, sapi betina akseptor (Peternak), pihak yang menjalankan IB (Inseminator), pihak yang mengatur dan menyelenggarakan pelatihan tenaga inseminator, pemeriksa kebuntingan $(\mathrm{PKb})$, Asisten Teknis Reproduksi (ATR) ternak dan pihak pasar ternak dan para pembeli. 
Dalam penyuluhan ini diuraikan tentang pengertian, tujuan dan manfaat IB serta tata kelola memperoleh layanan IB dan tugas pokok masing-masing pihak yang terkait dalam perjalanan kegiatan IB dan yang tidak kalah penting adalah penyamaan persepsi tentang factor-faktor penghambat kurang berkembangannya teknologi IB. Teknologi IB ini sudah diperkenalkan di daerah Nusa Tenggara Timur (NTT) sejak tahun 1976. Setelah IB diperkenalkan selama 41 tahun, ternyata IB masih terus berada pada tahap pengenalan. IB masih sulit untuk mencapai tahapan mandiri dan swadaya.

\section{Tujuan IB}

a. Memaksimalkan penggunaan Pejantan yang bergenetik unggul atau baik untuk meningkatkan mutu ternak.

b. Membantu perkawinan antar ternak yang berbeda ukuran tubuh, berbeda bangsa, berbeda tempat dan berjarak jauh antar ternak jantan dan betina.

\section{Manfaat IB}

a. Menghemat biaya, waktu dan tenaga mmemelihara pejantan unggul hanya untuk melayani jumlah betina akseptor yang jumlahnya terbatas.

b. Membantu peternak mendapatkan keuntungan yang lebih besar menjual ternak hasil IB daripada menjual ternak local.

c. Mempercepat waktu pemeliharaan sapi hasil IB (1-2 tahun) untuk mendapatkan ternak dengan nilai jual 2-3 kali lebih tinggi daripada memelihara sapi hasil kawin alam dengan pejantan local.

Untuk mendapatkan pelayanan IB pada ternak secara lebih baik dan berhasil, tidak terlepas dari pengaruh berbagai faktor yang dapat mendukung factor utama dan faktor pendukung. Ada beberapa factor utama keberhailan pelaksanaan layanan IB, yakni : Faktor ternak betina, faktor ternak jantan, faktor peternak, faktor tenaga teknis sedangkan faktor pendukung seperti sarana prasarana IB dan kebijakan pengembangan tenologi IB.

Pembukuan kadang-kadang dianggap kurang penting oleh peternak , padahal dengan pembukuan paling tidak ada 3 fungsi yang dapat diperoleh yaitu: perencanaan usaha, catatan pelaksanaan transaksi, penghitungan keuntungan dan mengontrol usaha. Ketiga fungsi tersebut merupakan bagian penting dalam manajemen usaha. Meskipun pembukuan masih 
sederhana dan belum menggunakan sistem akuntansi yang standard, ketiga fungsi tersebut seharusnya dapat diperoleh agar pembukuan efektif.

Penyuluhan tentang perencanaan usaha memberikan keterampilan peternak menghitung jumlah beberapa tanaman pakan yang harus ditanam berdasarkan produktivitas dan jarak panennya masing-masing untuk memeuhi kebutuhan sejumlah sapi yang dimiliki selama 1 tahun.

\section{Kegiatan Pelatihan Penyusunan ransum}

Kegiatan pelatihan penyusunan ransum dengan mempertimbangkan nutrisi yang dibutuhkan, dilakukan pada tanggal 2 Juli 2017. Kegiatan ini dihadiri oleh 47 peternak bersama dua orang mahasiswa pendamping. Dalam pelatihan tersebut berhasil disusun ransum sebanyak $20 \mathrm{~kg}$, untuk sapi Bali masa penggemukan. Ransum yang dihasilkan merupakan campuran dari beberapa komponen limbah usahatani yang tersedia di tingkat peternak, yaitu: tongkol jagung yang dicincang sebanyak $4 \mathrm{~kg}$, dedak padi sebanyak $4 \mathrm{~kg}$, jagung giling sebanyak $4 \mathrm{~kg}$, jerami padi yang telah dicincang sebanyak $6 \mathrm{~kg}$, dan daun lamtoro yang dicincang sebanyak 2 $\mathrm{kg}$.

Setelah ransum dibuat dan diujicobakan pemberiannya pada ternak ternyata tingkat kesukaan (palatabilitas) ternak sapi cukup baik. Melihat kondisi tersebut peternak peserta yang tadinya mengkuatirkan akan tingkat kesukaan ternak berniat untuk membuat ransum tersebut. Keinginan dan niat tersebut dapat dipahami karena selama ini peternak hanya mengandalkan hijauan segar baik dari rumput, legum maupun limbah pertanian. Jerami kering dan tongkol jagung selama ini merupakan limbah pertanian tanaman pangan yang tidak pernah dipergunakan sebagai pakan ternak bahkan dibuang begitu saja. Adanya alternatif pakan yang bersumber dari limbah tanaman pertanian ini dirasakan peternak sebagai sesuatu yang bermanfaat untuk mengatasi kekurangan pakan terutama pada musim kemarau. 

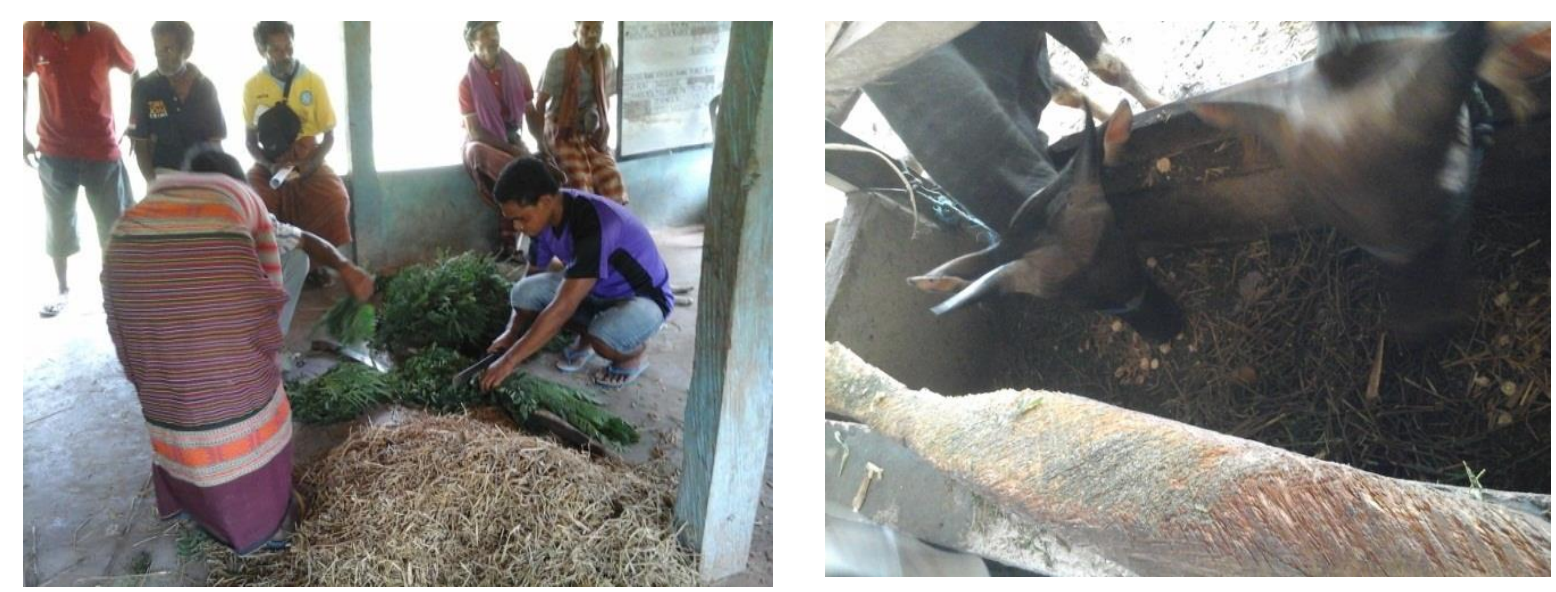

Gambar 2. Peternak Peserta Pelatihan dan Uji Coba Pembuatan Ransum

\section{Kegiatan Pelatihan Pembenahan Pembukuan Kelompok dan UBSP}

Kegiatan uji coba pembukuan kelompok dan UBSP dilakukan pada tanggal 3 Juli 2017. Kegiatan ini difokuskan kepada pengurus kelompok maupun UBSP kedua kelompok. Sebelum melakukan ujicoba pembukuan, terlebih dahulu tim melakukan evaluasi dan pembenahan terhadap pembukuan yang telah dibuat. Kegiatan ini didampingi oleh 2 orang mahasiswa pendamping.

Hasil evaluasi dan pembenahan menunjukkan bahwa pembukuan kelompok maupun UBSP belum dibuat secara baik. Kondisi yang didapatkan baru berupa catatan-catatan lepas dan belum dirangkum menjadi satu laporan keuangan tersistem. Untuk itu tim pelaksana mengarahkan, melatih dan mendampingi pengurus UBSP melaksanakan proses pencatatan keuangan UBSP berdasarkan sistem pembukuan yang lazim. Sistem pembukuan yang diajarkan ini sederhana sehingga mudah dipahami dan dilaksanakan oleh Pengurus secara mandiri. Selain itu, tim pelaksana menyediakan buku-buku dan format-format yang siap diisi atau yang bakal digunakan oleh pengurus UBSP. Selanjutnya akan dipantau dalam kegiatan pendampingan sehingga dapat dilakukan secara baik dan benar. 

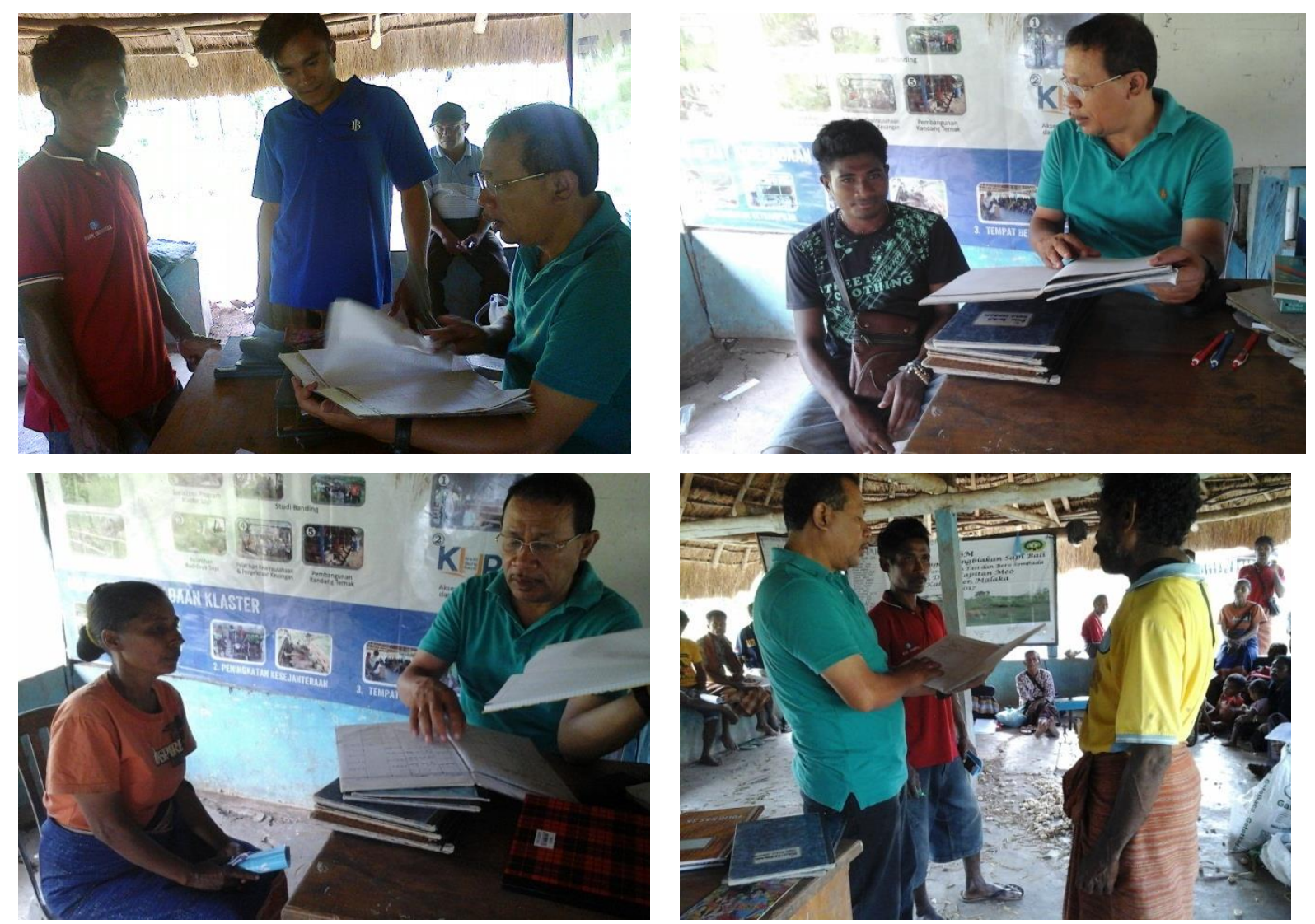

Gambar 3. Pelatihan Pembenahan Pembukuan KT Marin Tasi dan Bero Sembada

Proses pembukuan UBSP pada UBSP Marin Tasi dan Bero Sembada yang sedang dibenahi sbb:

1. Proses awal dimulai dari Buku Kas harian berdasarkan bukti-bukti transaksi yang ada.

Namun, berdasarkan hasil pengecekan pada umumnya pada kedua UBSP tidak

mengumpulkan dan mengarsipkan dengan baik bukti-bukti transaksi keuangan yang terjadi.

2. Proses selanjutnya dilakukan rekapitulasi dengan membuat Buku Kas Tabelaris untuk merekap semua transaksi kedalam komponen-komponen Aktiva, Hutang dan Modal serta Penghasilan dan Biaya; selanjutnya dihitung saldo masing-masing komponen tersebut per-bulannya.

3. Proses selanjutnya dibuat Kertas Kerja untuk merangkum semua komponen Aktiva, Hutang, Modal, Penghasilan dan Biaya setiap bulan sebaga persiapan untuk membuat Laporan Keuangan.

4. Proses terakhir adalah menyusun Laporan Keuangan, yang terdiri atas Laporan Posisi Neraca dan Perhitungan Laba/Rugi. 
Kendala yang dihadapi dalam melatih pembukuan UBSP di kedua Kelompok ini adalah: ketrampilan pengurus dalam pembukuan masih rendah, waktu yang disediakan untuk melaksanakan pencatatan sangat terbatas karena kesibukan-kesibukan rutinitas mereka dan pengalaman masa lalu anggota yang merasa tidak puas terhadap kinerja pengurus. Untuk itu dibutuhkan proses pendampingan bagi pengurus agar dapat mandiri dalam melaksanakan pembukuan UBSP secara baik dan benar, bertanggung jawab dalam melaksanakan tugas, dipercaya anggota dan mampu mewujudkan tanggung jawab tersebut dalam bentuk pelaksanaan RAT tepat waktu.

\section{SIMPULAN DAN SARAN}

Berdasarkan pelaksanaan kegiatan dan hasil yang telah dicapai, dapat disimpulkan beberapa hal:

1. Kegiatan IbM menyangkut semua aspek terkait usaha pengembangbiakan sapi Bali, kelembagaan kelompok, dan UBSP sangat bermanfaat untuk meningkatkan pengetahuan, pemahaman, dan keterampilan peternak pada kedua kelompok tersebut tentang manajemen pakan, perkandangan, pembibitan, dan pembukuan.

2. Pemanfaatan limbah tanaman pangan dan bahan pakan lainnya yang terdapat disekitar peternak sebagai komponen penyusunan ransum dengan nutrisi cukup meningkatkan pengetahuan sekaligus keterampilan peternak.

3. Keterampilan pengurus tentang sistem pembukuan keuangan UBSP dan kelompok yang baik dan benar diperlukan untuk meningkatkan kepercayaan peternak anggota, keberlanjutan UBSP sendiri, dan bila perlu ditingkatkan menjadi koperasi sehingga dapat memenuhi berbagai kebutuhan peternak dan mendukung keberlanjutan usaha ternak sapi.

4. Terselenggaranya penyuluhan, pelatihan, dan ujicoba ini telah merupakan salah satu langkah terciptanya kerjasama antara kelompok mitra dengan tim pelaksana yang mewakili Undana dalam mengatasi persoalan pembangunan peternakan di NTT.

Berdasarkan kesimpulan di atas maka beberapa saran yang diperlukan adalah:

1. Peningkatan frekuensi kegiatan yang sama dengan materi penyuluhan dan pelatihan yang berbeda untuk meningkatkan pengetahuan, pemahaman, dan keterampilan peternak yang memiliki keterbatasan dalam menjangkau teknologi praktis dan adaptif. 
2. Perlu diperkenalkan berbagai bahan pakan alternatif lainnya yang terdapat di sekitar peternak agar dimanfaatkan secara optimal untuk pengembangan usaha ternak sapi Bali.

3. Hal-hal mendasar lainya yang perlu dibenahi selain pembukuan, adalah: penyusunan anggaran dasar, anggaran rumah tangga, dan pembukuan anggota,

\section{DAFTAR PUSTAKA}

Belli, H.L.L. 2010, Pemilihan Bakalan Ternak Sapi. Makalah. Disajikan pada Pengabdian Fakultas Peternakan Undana di Besipae, Timor Tengah Selatan.

Krova, M. 2015. Rancang Bangun Pengembangan Agribisnis Sapi Bali di Kabupaten Belu dan Malaka, Nusa Tenggara Timur. Disertasi. Universitas Padjadjaran Bandung.

Porter, M. E. 1998. Cluster and the New Economics of Competition. Reprint 98609. Harvard Business Review.

Tenang dan Karo, S. M. 2014. Peranan dan Fungsi Ternak pada Praktik Belis dalam Ritual Perkawinan Adat Suku Kemak di Wilayah Belu Utara Kabupaten Belu, Nusa Tenggara Timur. Jurnal Ilmu-Ilmu Sosial, Volume XII Nomor 2, April 2014. 